Michał Grala

ORCID: 0000-0003-1596-063X

Uniwersytet Wrocławski

https://doi.org/10.19195/1733-5779.38.2

\title{
Profesjonalizacja branży usług seksualnych w kontekście rozwoju narzędzi wizerunku i kanałów dystrybucji treści
}

Słowa kluczowe: wizerunek, seks, prostytucja, marketing

Keywords: image, sex, prostitution, marketing

\begin{abstract}
Abstrakt: Tematem pracy jest analiza profesjonalizacji branży usług seksualnych w kontekście rozwoju narzędzi wizerunku i kanałów dystrybucji treści. Rekonstrukcja historii zjawisk seksualności i cielesności w omawianym kontekście komercjalizacji pozwala nakreślić, jak kształtował się normatyw. Jego renegocjacja, odbywająca się za pośrednictwem mediów, stwarza warunki do poszerzenia grup odbiorców poprzez nadawanie przez nich znaczeń. Stymulowanie dywersyfikacji produktów ekwiwalentnych jakościowo odbywa się więc na zasadzie optymalizacji komunikacji na linii oferenci-ich publiczności. Analiza wykazała nie tylko rekonstrukcję samego normatywu, lecz także dyfuzję kanałów dystrybucji treści. Narzędzia budowania wizerunku, stymulacji sprzedaży i pozycjonowania produktów budowane są przez wykorzystanie marketingu 360 . Następstwem tego jest wkraczanie produktów i usług w środowiska do tej pory nowe. Analiza prowadzona na próbie 320 ogłoszeń towarzyskich, a także analiza danych wtórnych, pochodzących z zewnętrznych raportów, w połączeniu z analizą ruchu w sieci, dają podstawy do stwierdzenia, że branża upowszechnia i profesjonalizuje podejście do seksu jako towaru. Nie tylko adaptowane są nowe rozwiązania technologiczne, budujące sieci, lecz także przede wszystkim rośnie krąg osób przygotowujących profesjonalnie swoje produkty na tej płaszczyźnie.
\end{abstract}

\section{Professionalization of the sex industry in the context of developing image tools and content distribution channels}

Abstract: The subject of the work is analyzing the professionalization of the sex industry in the context of the developed image tools and content distribution channels. Reconstructing the historical perspective on the phenomenon of sexuality and corporeality in the context of commercialization allows us to outline a norm. Its renegotiation, taking place through the media, creates the conditions for expanding the audience. Thus, the stimulation of diversifying qualitatively equivalent products takes place on the basis of optimizing the communication between the bidder and their audience. The analysis showed not only the reconstruction of the norm itself, but also the 
diffusion of content distribution channels. Tools for image building, sales stimulation, and product positioning are built through the use of 360 marketing. The consequence of this is the entry of products and services into the environment that has been new until now. Empirical research conducted on a sample of 320 ads, as well as the analysis of secondary data from external reports in conjunction with the analysis of web traffic give grounds to conclude that the industry promotes and professionalizes the approach to sex as a commodity. Not only are new technological solutions adopted that build networks, but also, most of all, the circle of people who prepare their products professionally in this area is growing.

Seksualność, nagość, cielesność to obszary tematyczne interesujące specjalistów z wielu dziedzin: psychologii, socjologii czy kulturoznawstwa. W swych opracowaniach podejmują oni rozmaite ich aspekty. Przemiany społeczne, urynkowienie coraz to nowych obszarów czy renegocjacja tabu związanego z tą tematyką skłaniają do analiz ich komunikacyjnego aspektu. Jako jeden $\mathrm{z}$ istotnych kontekstów dla tej tematyki wskazać należy wejście społeczeństw w sferę kultury konsumpcyjnej. Konsekwencją tego zjawiska jest koncentracja na ciele jak pisze Richard Shusterman: „,nasza kultura jest coraz bardziej zaabsorbowana ciałem"1. Dynamika tych przemian jest wysoka. Zbigniew Lew-Starowicz zauważa, że uwydatniają się one nie tylko w rosnącej społecznej akceptacji kohabitacji i seksu przedmałżeńskiego, stopniowej liberalizacji postaw wobec nieheteronormatywnych seksualności, lecz także w bardziej pozytywnym podejściu do ciała, przyjemności seksualnej oraz partnerstwa ${ }^{2}$. Jednak bez względu na finalny efekt i obecny kształt tych przemian warto dodać, że pewnego rodzaju wsparciem dla procesów kształtowanych oddolnie jest profesjonalizacja komunikacji. Rozumieć ją można jako wykształcenie wyspecjalizowanych narzędzi służących nadawaniu znaczeń i budowaniu lub renegocjacji semantyki w obrębie seksualności, nagości i cielesności.

Trudno również ignorować fakt, że ,seks staje się coraz bardziej [...] skomercjalizowany i utowarowiony"3. Wspomniane przemiany społeczne oswajają ciało, nagość i seksualność. Tak rozumiana fizyczność staje się przedmiotem handlu. Jak pisze Zbyszko Melosik:

W społeczeństwie konsumpcji ludzie są coraz częściej postrzegani przez pryzmat swoich ciał. Tożsamość jest stopniowo wymywana z tego, co tradycyjnie nazywano umysłem lub duszą, i przenoszona „na powierzchnię” — zaczyna być odgrywana przez ciało ${ }^{4}$.

${ }^{1}$ R. Shusterman, O sztuce życia. Od poetyki hip-hopu do filozofii somatycznej, przeł. W. Małecki, Wrocław 2007, s. 95.

2 Z. Lew-Starowicz, Miłość i seks. Stownik encyklopedyczny, Wrocław 1998, s. 13.

3 A. Stein, Three Models of Sexuality. Drives, Identities and practices, [w:] Sexualities. Critical Concepts in Sociology, t. 1, red. K. Plummer, London-New York 2002, s. 245.

${ }^{4}$ Z. Melosik, Tożsamość, ciało i władza. Teksty kulturowe jako (kon)teksty pedagogiczne, Poznań 1996, s. 38. 
Francuski socjolog Marcel Mauss pisze, że ciało jest nie tylko elementem historii naturalnej, lecz także społeczno-kulturowej i nie podlega wyłącznie prawu jednej z nich ${ }^{5}$. Rozważania na temat profesjonalizacji branży usług seksualnych należy rozpocząć od krótkiego zarysu dziejów roli cielesności i seksualności w kulturze. Istotne jest tu zwłaszcza uwzględnienie procesów, które spowodowały taki, a nie inny model postrzegania cielesności. Ze względu na obszerność zagadnienia ograniczono zarys chronologicznie i terytorialnie.

\section{Kształtowanie się postrzegania seksualności i cielesności w kulturze}

Pominąwszy prehistoryczne zachowania plemienne, rozważania należy rozpocząć od procesów, które odegrały istotną rolę w kształtowaniu się cywilizacji naszego kręgu kulturowego. Mowa tu o rozciągniętych w czasie i niejednorodnych procesach dotyczących obszarów starożytnego Wschodu, basenu Morza Śródziemnego i współczesnej Europy. Zwłaszcza dziedzictwo starożytności ma decydujący wpływ na nasz obszar kulturowy.

Nagość w starożytności była tolerowana w znacznie większym stopniu niż obecnie. Igrzyska organizowane w starożytnej Grecji były emanacją kultu ciała - nagiego i eksponowanego bez wstydu ${ }^{6}$. Sztuka grecka, dążąca w swojej istocie do ideału, posługiwała się nagością w celu przedstawienia idealnych proporcji i kształtów ciała. Seks, zarówno heteroseksualny, jak i homoseksualny, był powszechnie akceptowany. Sam akt i jego forma nie stanowiły powodu do wstydu, mogły wręcz odnosić się do zamożności oraz pozycji społecznej mężczyzn ${ }^{7}$. Również związków między kobietami nie uznawano za gorszące ${ }^{8}$. Seksualność funkcjonowała w życiu religijnym, literaturze i sztuce wizualnej. Była ściśle związana z kultami Afrodyty i Dionizosa, a także obecna w greckiej mitologii.

Schedę fundamentów kultury, w tym i podobnego traktowania nagości i seksualności, przejęli od Greków Rzymianie. Traktowali oni nagość w łaźniach jako rzecz naturalną. Seksualność wkroczyła na kolejny poziom, wiążąc z hedonizmem. Stała się nie tylko narzędziem prokreacji, lecz także przyjemności. Pojawiły się opisane przez biografów akty perwersji seksualnych Tyberiusza czy Kaliguli. Przetrwały nieprzyzwoitej treści freski w zniszczonych Pompejach. Zakładając niewielki odsetek dzieł starożytnych, które przetrwały do dziś, można zaryzykować stwierdzenie, że seksualność była motywem często wykorzystywanym przez twórców tamtej epoki. Odniesienia do nagości (na przykład traktowanie nagości w łaźniach przez Rzymian) i seksualności jako naturalnej sfery istnienia były powszechne.

5 M. Mauss, Socjologia i antropologia, przeł. M. Król, K. Pomian, J. Szacki, Warszawa 2001, S. 391.

6 J. Swaddling, Starożytne igrzyska olimpijskie, przeł. J. Lang, Poznań 2004, s. 7.

7 K.J. Dover, Homoseksualizm grecki, przeł. J. Margański, Kraków 2004, s. 10.

8 Ibidem, s. 13. 
Istotne przemiany kulturowe w omawianej tu sferze zaszły w średniowieczu. Kościół katolicki napiętnował nagość i poprzykrywał penisy antycznych rzeźb figowymi listkami. Jedyną formą przedstawiania nagości, akceptowaną przez Kościół, były reprezentacje pasji Chrystusa, nagości Adama i Ewy czy grzeszników potępionych w piekle ${ }^{9}$. Atrybuty seksualności dyskretnie przysłaniano perizonium czy motywami roślinnymi. Zgodnie z doktryną Kościoła poczucie wstydu, odkrycie swojej nagości u Adama i Ewy były elementem kary za grzech i wyrazem noszenia w sobie jego piętna ${ }^{10}$. Nabierająca wyrazu i siły rola grzechu łączyła nagość i seksualność z odczuciem wstydem. Nie można pominąć w tych rozważaniach kultury ludowej, która w zasadzie do dziś traktuje seks i cielesność, w kontekście rubasznych przyśpiewek czy niezdarnych rysunków erotycznych ${ }^{11}$. Podobnie jak w przypadku starożytności, tak i w średniowieczu proces przemian traktowania cielesności przebiegał nieliniowo i wielopoziomowo. Obowiązywał inny stosunek do nagości kobiecej, a inny — do męskiej. Jak pisze Georges Duby:

Kobiecie przypisano sytuację wstydu, godną pożałowania formę ekshibicjonizmu, obnażona wydaje się funkcjonować w sytuacji pozbawionej praw socjalizacji ciała. Funkcja nagiego mężczyzny wydaje się ściśle związana ze społecznymi rytuałami, z oznakami spójności grupy, poddawanej nieustannym próbom [...]. Ubranie dla mężczyzny było oznaką wewnętrznej integracji, potwierdzonej przez kolektyw ${ }^{12}$.

Nauczanie Kościoła ograniczało nagość tylko do ściśle określonej prywatnej przestrzeni i nadawało seksualności status czegoś, co miało prawo odbywać się tylko w nocy ${ }^{13}$.

Renesans przynosi zmiany w średniowiecznym światopoglądzie i pozwala zobaczyć nagość w nowej perspektywie. Po latach ukrywania ciała zaczęto zdejmować kolejne warstwy ubrań i ponownie zwrócono uwagę na różne aspekty ciała. Nagość oswajała medycyna, rozwijana przez potajemne studia nad anatomią, choć tak jak i inne dziedziny życia, znajdowała się ona pod bardzo wyraźnym oddziaływaniem religii. Lekarze, rozpoznając przyczyny chorób i zalecając metody ich leczenia, kierowali się bardzo często zaleceniami Kościoła ${ }^{14}$. Źródłem wszelkiej mądrości było Pismo Święte.

Sztuka powróciła do aktu jako formy wyrazu, jednak ciągle pod kuratelą wielkiego mecenasa sztuki - Kościoła. Zaczęto oficjalnie przyznawać, że seksualność daje radość, choć zachowały się z tych czasów płócienne wory z otworami

9 M. Hankus M, ,Powabny wydźwięk ciat” a kreacja nowej sztuki religijnej, ,Zeszyty Naukowe Towarzystwa Doktorantów UJ Nauki Humanistyczne" 2011, nr 3, s. 16.

10 J. Kalwin, Zasady religii chrześcijańskiej (1559-1560), [w:] Historia doktryn artystycznych, t. 2, Teoretycy, pisarze i artyści o sztuce 1500-1600, red. J. Białostocki, Warszawa 1985, s. 128.

11 J. Łojek, Nagość ciała w obyczajowości i kulturze Europy, „Teksty” 1977, nr 3, s. 90.

12 Historia życia prywatnego, t. 2, red. G. Duby, Wrocław 1998, s. 405.

13 M. Hankus, op. cit., s. 19.

14 J.A. Kultys, Moralność a seks i kobiety (w wybranych kulturach), Słupsk 1999, s. 243. 
na narządy płciowe, wykorzystywane jako stroje podczas uprawiania seksu - ta dwoistość jest jednym z przykładów niejednoznaczności kulturowych przemian. Nadal piętnowano masturbację, którą uznawano za czyn zdrożny, prowadzący do ślepoty, ogłupienia i potępienia.

Zmiany w pojmowaniu seksualności przyniósł, szerzący się od XVI wieku w Europie, a później też w Ameryce Północnej, protestantyzm. Marcin Luter głosił, że w teologicznym rozumieniu: „namiętny i naturalny pociąg do kobiety [...] to słowo i dzieło Boga"15. W większym stopniu do alkowy powrócił seks uprawiany dla przyjemności. To stworzyło pole do działania holenderskim mistrzom, którzy bez skrępowania malowali akty. Największe znaczenie dla dynamiki zmian w tej dziedzinie miało częściowe oderwanie sztuki od Kościoła. Odbiorcami i mecenasami sztuki stali się bogaci mieszczanie, zwłaszcza protestanci północnej Europy i światli mieszczanie republik kupieckich południa kontynentu. Kościół starał się zwalczać przemiany. Kwintesencją jego konserwatyzmu był sobór trydencki - początek kontrreformacji. Index librorum prohibitorum ograniczył dostęp do wszystkiego, co nie było zgodne z doktryną i moralnością Kościoła katolickiego. Nastąpił rozłam postaw wobec seksualnej sfery życia. Obok Henryka VIII, męża sześciu żon, rozwodnika, odstępcy od Kościoła, czy rozpusty francuskiego szesnastowiecznego dworu królewskiego, funkcjonują takie wzorce wstrzemięźliwości jak Ignacy Loyola i jego jezuici czy angielscy purytanie.

Kolejne epoki przyniosły dalszą ewolucję. Cielesność uzyskiwała status estetycznej, stając się ponownie natchnieniem. Seksu zaś ciągle strzegła moralność, umacniana w poprzednich epokach. Proces ten zachodził znacznie wolniej niż zmiany postrzegania nagości. Ta zyskiwała bowiem przymioty estetyki i artyzmu. Zasadniczym przełomem, bardzo istotnym także w omawianych dziedzinach, były rewolucyjne przemiany społeczne końca XVIII wieku. Wielkie przemiany społeczne przyniosła rewolucja francuska dająca władzę mieszczanom i rewolucja przemysłowa tworząca kapitalistów i robotników. Szybkie upowszechnienie się druku stało się początkiem kultury masowej ${ }^{16}$. Pojawiły się pierwsze drukowane przedstawienia pornograficzne ${ }^{17}$. Swoboda obyczajowa dotyczyła jednak głównie dużych miast. Wieś i szeroko pojęta prowincja pozostawały nadal konserwatywne, choć cieszyły się jednocześnie rubaszną prostotą.

Istotne zmiany przyniósł przełom XIX i XX wieku. Rok 1886, w którym wydano pracę Psychopatia sexualis Richarda Krafta-Ebinga, uważa się za początek

15 E. Adamiak, Kobieta w Kościołach $i$ wspólnotach chrześcijańskich. Próba syntezy teologicznej, „Poznańskie Studia Teologiczne” 11, 2011, s. 101.

16 E. Kuraciński, Wyznaczniki kultury masowej, „Seminare. Poszukiwania naukowe”21, 2005, s. 412.

17 M. Beck, The Roots of Western Pornography. The French Enlightenment takes on sex, Oxford 2003, s. 20. 
seksuologii ${ }^{18}$. W tym okresie kształtuje się też nowoczesna państwowość, następują przemiany kultury, pojawiają się nowe zjawiska. Procesy te przyczyniły się do utraty znaczenia Kościoła i katolickiej moralności w stopniu większym niż dotychczas wszystkie inne przemiany kulturowo-społeczne ${ }^{19}$. Pojawiło się zjawisko emancypacji kobiet, które doprowadziło do innego postrzegania ich aktywności seksualnej. Dwutorowo rozwijało się także pozytywne traktowanie nagości. Z jednej strony medycyna oswajała widok nagiego ciała, z drugiej artyści wykorzystywali je jako natchnienie i dzieło sztuki. Co ciekawe, znacznie wolniej ewoluowała sfera moralności. Seks oficjalnie ciągle był postrzegany jako narzędzie prokreacji. Różnica w traktowaniu seksualności, w porównaniu do średniowiecza, renesansu czy czasów reformacji była znaczna, jednak nie rewolucyjna.

Prawdziwym przełomem w seksualności było wynalezienie i propagowanie nowoczesnych środków antykoncepcyjnych. Prezerwatywy, które do powszechnego użycia weszły pod koniec XIX wieku, skierowały seksualność na nowe tory. Dwie wojny światowe oraz przemiany polityczno-społeczne, które ze sobą przyniosły, pozwoliły na pełniejszą emancypację kobiet. W 1961 roku do sprzedaży trafiła pierwsza tabletka antykoncepcyjna - Anovlar. Ludzie dostali narzędzie, dzięki któremu mogli częściej i bezpieczniej oraz bez skrępowania i obawy uprawiać seks dla przyjemności i zabawy. Hippisowska wolność seksualna lat sześćdziesiątych XX wieku dodatkowo zmieniła postrzeganie ciała i nagości. Swobodne współżycie, a nawet wolna miłość w komunach, coś, czego nie można było robić na taką skalę przez wieki, stały się możliwe. Przemiany te nie dotknęły wszystkich miejsc na świecie i nie nastąpiły w tym samym czasie, jednak ich siła, symboliczny wymiar, były tak wielkie, że nazwano ten okres rewolucją seksualną ${ }^{20}$.

Funkcjonujemy dziś w czasach porewolucyjnych, obcując z różnymi odmianami i różnym traktowaniem nagości. Wielkie koncerny korzystają z nagości i cielesności w kampaniach reklamowych. Wątki te pojawiają się w sposób zarówno bardzo jawny, jak i mniej widoczny, nie są od nich wolne w zasadzie żadne reklamy. Erotyka w reklamie przybiera różnorodne formy, od niewinnego erotyzmu dziecięcego, przez miękką erotykę, aż po mocne, często wulgarne sceny lub niesmaczne żarty ${ }^{21}$.

Co oczywiste, sama perspektywa postrzegania nagości zależna jest nie tylko od kontekstu, w którym nagość się pojawia, lecz także od kultury, w której osadzony

18 M. Leśniewski, Narodziny seksuologii - zarys stanu wiedzy lekarskiej o seksualności człowieka na przełomie XIX i XX wieku, [w:] Kobieta i rewolucja obyczajowa. Społeczno-kulturowe aspekty seksualności. Wiek XIX $i$ XX, red. A. Żarnowska, A. Szwarc, Warszawa 2005, s. 12.

19 A. Jasińska-Kania, Wartości i normy moralne a procesy przemian w Polsce i Europie, [w:] Wartości, postawy i więzi moralne w zmieniającym się społeczeństwie, red. J. Mariański, L. Smyczka, Kraków 2008, s. 15.

20 J. Petry Mroczkowska, Amerykańska rewolucja seksualna — nie spetniona obietnica szczęścia, „Ethos” 32, 1995, nr 4, s. 245.

${ }^{21}$ M. Wojciechowski, Erotyka w mediach. Szansa czy zagrożenie dla rozwoju mtodego pokolenia?, Kraków 1998, s. 5. 
jest odbiorca: „ciało społeczne określa sposób, w jaki postrzegamy ciało fizyczne. [...] Pomiędzy tymi dwoma rodzajami doświadczania ciała zachodzi ciągła wymiana znaczeń w taki sposób, że jedno wzmacnia kategorie drugiego"22. Jest to zjawisko o dynamicznie zmieniającym się w obszarze kultury, niejednorodnym kształcie. Obecnie funkcjonujące modele normatywne powstały na kanwie wspomnianej wcześniej rewolucji seksualnej. Jej skutki dotyczące wzorców moralnych nie doprowadziły jednak do powszechnej eskalacji swobód seksualnych. Tradycja pokoleniowa, religijność obawa przed AIDS zachowują tabu, czasami jednak tylko w aspekcie fasadowym.

Odrębną kwestią jest komercjalizacja zjawiska seksualności i cielesności. Warto w tym miejscu odnieść się do technicznego postępu cywilizacji. Okazuje się bowiem, że pierwsze fotografie o treści seksualnej powstały w okolicach roku 1840, a więc już rok po wynalezieniu aparatu fotograficznego. $Z$ jednej strony jest to zaskakujące, z drugiej zaś można traktować to jako swego rodzaju przedłużenie tradycji malarskich. Pierwsze zdjęcia i ich modelki nie zyskały społecznego pokla$\mathrm{sku}^{23}$. Przez wiele lat deprecjonowano fotografię jako dziedzinę sztuki. Narodziny filmu również wiążą się z pojawieniem się podobnego zjawiska. Komercjalizacja seksualności i cielesności przy użyciu nowoczesnych narzędzi wizerunkowych to kwestia wieku XX i mediów, które w tym okresie powstały ${ }^{24}$. Gwałtowny rozwój prasy, wydawnictw książkowych, później radia, powodował przekaz szerokiego spektrum informacji, we wszystkich kierunkach. Grono odbiorców kultury poszerzyło się poza dotychczasowy krąg złożony z przedstawicieli dworów, arystokracji, bogatych mieszczan i przedstawicieli Kościoła.

Całkowitym otwarciem się wszystkich aspektów seksualności, zjawisk kultury i wymiany informacji stał się internet. Ogromną część jego zawartości stanowią treści pornograficzne i erotyczne, dostępne o każdej porze, w zasadzie dla każdego użytkownika. Pojawia się interaktywność przekazu i wiele zjawisk do tej pory nieznanych. Wydaje się, że internet jest fundamentem kolejnej ewolucji postaw, przemian obyczajowych i społecznych o niespotykanym zasięgu i nieznanej dotąd szybkości i różnorodności.

\section{Komercjalizacja zjawiska cielesności}

Badania wizerunku w omawianym w kontekście mogą zajmować się, z jednej strony, samym postrzeganiem nagości i seksualności, z drugiej zaś rekonstrukcją bardziej metodycznego podejścia związanego z profesjonalizacją komunikacji. Komercjalizacja nagości i seksualności wydaje się warunkiem, który dobrze od-

22 M. Douglas, Czystość i zmaza, przeł. M. Bucholc, Warszawa 2007, s. 111.

23 L.M. Nijakowski, Pornografia. Historia, znaczenie, gatunki, Warszawa 2010, s. 232.

24 M. Ciereszko, Popularna pornografia? O rodzajach pornografii funkcjonujacych na ziemiach polskich na poczatku XX wieku i jej relacji z ówczesną kultura popularna, „, Kultura i Historia" 2016, nr 296, s. 3. 
daje taką perspektywę. Otoczenie konkurencyjne oraz instytucjonalność sprzyjają profesjonalizacji całego badanego obszaru ${ }^{25}$. Obok analizowania dyskursu obejmującego media głównego nurtu i ich treści, warto spoglądać w stronę branż, których głównym celem jest monetyzacja erotyki oraz cielesności w kontekście seksualnym. Na tej podstawie można zaryzykować stwierdzenie, że analiza komercjalizacji w tych obszarach dotyczyć powinna dwóch głównych pól: pornografii i prostytucji. Oba stanowią swego rodzaju emanacje cielesności, tworzone z myślą o sprzedaży. W refleksji Michela Foucaulta ciało człowieka jest plastycznym tworem. Francuski badacz pisze, że ciało „to system znaków społecznych, kształtowanych i uwikłanych w relację władzy"26. Podmiotowość ciała w kontekście komercjalizacji jest odzwierciedleniem systemu znaczeń społecznych, stanowi wyraz danego społeczeństwa: „mówienie o ciele może równocześnie być mówieniem o społeczeństwie" ${ }^{27}$. O ile artyście tworzącemu akt towarzyszyć może myśl o odwzorowaniu kobiecego piękna, o tyle przedstawienie pornograficzne to: „wizerunki o treści nieprzyzwoitej, obscenicznej, przedstawiające sceny erotyczne, aby podniecić seksualnie widza" 28 .

Podobnie jak w przypadku rysu historycznego dotyczącego cielesności, tak i tu warto przyjrzeć się ewolucji samego pojęcia i nie kojarzyć pornografii wyłącznie ze współczesnością.

Pierwszych przedstawień tego typu doszukać się można już w naskalnych rysunkach plemion wspólnoty pierwotnej. Prehistoryczne rzeźby bogini płodności prawdopodobnie również wkraczały w ten obszar. W naszym kręgu kulturowym przedstawienia pornograficzne pojawiły się już w starożytnej Grecji (motywy w malarstwie czarno- i czerwonofigurowym okresu klasycznego). Pornografię wyrugowała (z jawnego życia) średniowieczna moralność kreowana przez Kościół. W erze nowożytnej, mimo świadomości jej istnienia, pornografia była zjawiskiem marginalnym. Dopiero w czasach wiktoriańskich stała się bardziej powszechna. Dominacja obrazu w dziedzinie pornografii to wynik rozwoju fotografii stereoskopowej, upowszechnionej następnie za pomocą fotoplastykonu. Kiedy w 1895 pojawiło się kino, prawie natychmiast zaczęły powstawać pierwsze produkcje o charakterze pornograficznym. Datę powstania tych dzieł określa się prawie jednocześnie z wynalazkiem filmu jako takiego, czyli 1895 roku. Pionierami byli Eugène Pirou i Albert Kirchner, autorzy najstarszego znanego filmu pornograficznego - Le Coucher de la Marie ${ }^{29}$. Obecnie pornografia to potężny przemysł, wykorzystujący najnowszą technikę, angażujący ogromne środki finansowe, mający

25 Leksykon Public Relations, red. J. Olędzki, D. Tworzydło, Rzeszów 2009, s. 141.

26 M. Foucault, Body/Power, [w:], idem, Power/Knowledge, red. G. Colin, London 1980, s. 58.

${ }^{27}$ H. Jakubowska, Ciało i seksualność jako narzędzie przyjemności i źródło cierpienia, [w:] Przemiany seksualności, red. M. Kaczorek, K. Stachura, Gdańsk 2009, s. 118.

${ }^{28}$ W. Kopaliński, Pornografia, [hasło w:] idem, Stownik wyrazów obcych i zwrotów obcojęzycznych, Warszawa 1989, s. 373.

${ }^{29}$ L.M. Nijakowski, op. cit., s. 20. 
potencjalnie nieograniczony zasięg. Jest coraz większy, globalny dzięki najnowszemu medium — sieci internetowej. Według analiz Alexa.com największa strona $\mathrm{z}$ pornografią jest sklasyfikowana $\mathrm{w}$ rankingu popularności zaraz za portalami mediów społecznościowych. Strony pornograficzne wyprzedzają w top 20 takich gigantów jak Amazon, Netflix czy popularny w czasie lockdownu Zoom. Co ciekawe, normalizacja zjawiska płatnego seksu w formie online czy włączenie do dyskursu słowa sex worker bez pejoratywnego zabarwienia, jest efektem coraz szerzej eksponowanego zjawiska. Sex worker to osoba zajmująca się nie tylko prostytucją, lecz także pracą w szeroko pojętej branży dostarczania uciech cielesnych. Mowa tu o rozbieraniu się za pieniądze, masażach erotycznych i tym podobnych aktywnościach. Wiele osób wybrało takie zajęcie, czego dowodzi ponad ośmiopoziomowy przeskok miernika wzrostu zainteresowania omawianą kategorią twórczości w największych serwisach internetowych oferujących pornografię. Według raportu Pornhub (największego gracza na rynku) przyrost treści od kobiet klasyfikowanych jako ,amatorki”, a także wzrost zainteresowania treściami oznaczanymi tą frazą uczynił ją numerem jeden roku 2019. Ruch wygenerowany przez 10 najpopularniejszych profili to 1544009675 użytkowników. Serwis deklaruje roczny przyrost 98 tys. nowych osób szukających takiego rodzaju kariery dla siebie ${ }^{30}$. Sam serwis zaangażowany jest w obszerne działania w social mediach i proponuje swoim użytkownikom różnego rodzaju wyzwania, polegające na publikacji treści określonego rodzaju. Obok platform sprzedających treści pornograficzne rośnie więc serwis społecznościowy, będący odpowiednikiem Facebooka z treściami seksualnymi.

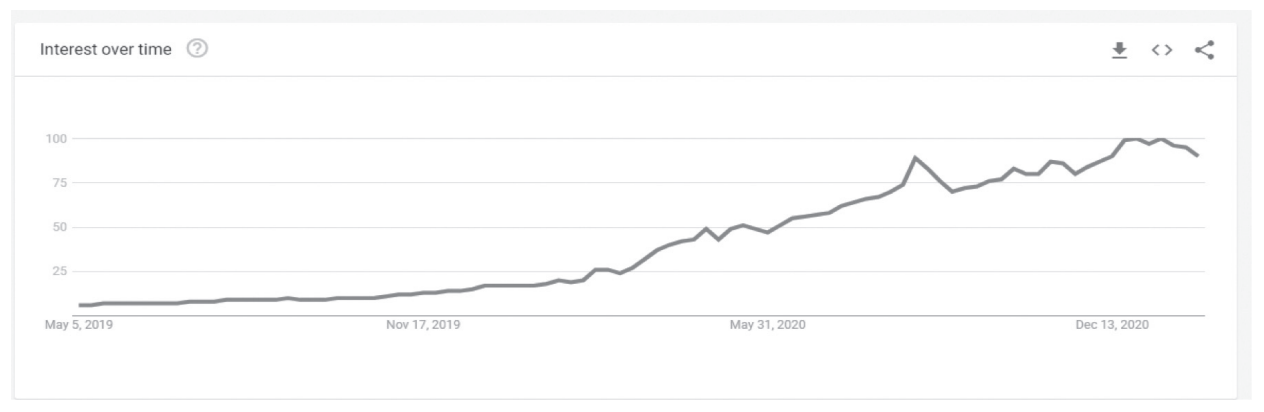

Wykres 1. Popularność serwisu Onlyfans w okresie od 2 maja 2019 do 2 maja 2020

Źródło: opracowanie własne.

Popularność serwisu Onlyfans rośnie nie tylko w odniesieniu do oglądających, lecz także twórców oferujących płatne treści o charakterze seksualnym. Według danych Influencer Marketing Hub przyrost treści i widzów w ciągu roku (20192020) wyniósł 557\%. Dziś wyniki są równie imponujące. Codziennie pojawiają

30 Źródła danych: pornhub.com/insights/2019-year-in-review (dostęp: 20.10.2021). 
się nowi oferenci takich treści. Jest ich około 5500 każdego dnia. Sprzedawanie swojej seksualności to formy promocji, po które sięgają nie tylko twórcy produkujący treści w domowym zaciszu, lecz także celebryci. Kariera Kim Kardashian nabrała rozpędu po publikacji seks taśmy. Zainteresowanie obudowane otoczką skandalu pozwoliło wykorzystać zjawisko datowane na lata dwudzieste XX wieku i rozpowszechnione za sprawą Phineasa Taylora Barnuma. Maksyma: nieważne, co mówią, byleby nie przekręcali nazwiska ciągle ma się dobrze. Etyka oraz wartość przekazu nie odgrywają tutaj żadnej roli. Celem jest bycie w centrum zainteresowania, nie zaś długofalowe budowanie zaufania i pozytywnego wizerunku. W Polsce przykładem karier zbudowanych w tym kanonie jest Marta Linkiewicz, chwaląca się uprawianiem grupowego seksu oralnego w autobusie, czy youtuberka Natsu, tworząca kontent dla nastolatków. Budowanie rozpoznawalności na sprzedaży własnej seksualności zostało szybko zmonetyzowane. Po pojawieniu się zdjęć i nagrań Natsu ogłosiła, że do sprzedaży trafi jej własna linia kosmetyków. Wzrost zainteresowania i datę premiery kosmetyków łatwo można połączyć z wykresem ukazującym popularność zapytań.

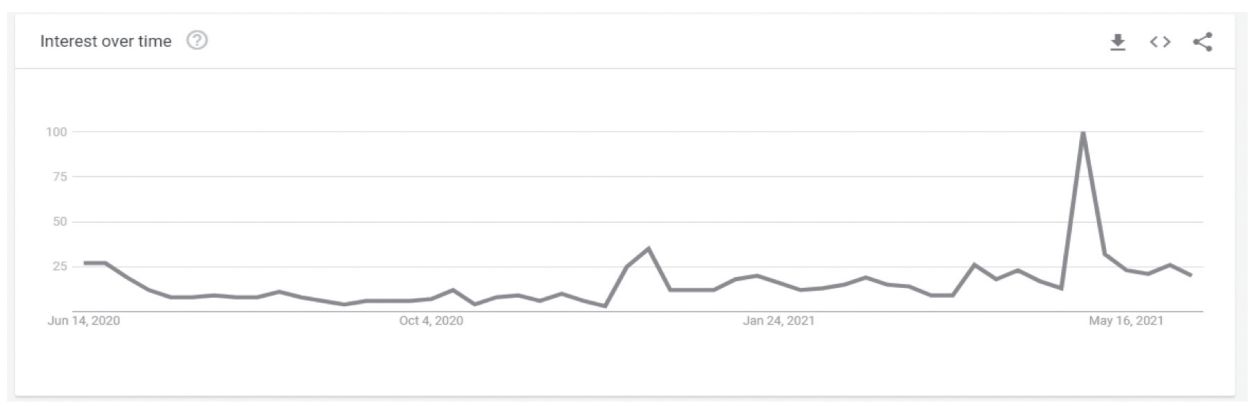

Wykres 2. Zainteresowanie youtuberką Natsu

Źródło: opracowanie własne.

Interest over time ?

$\pm\langle<$

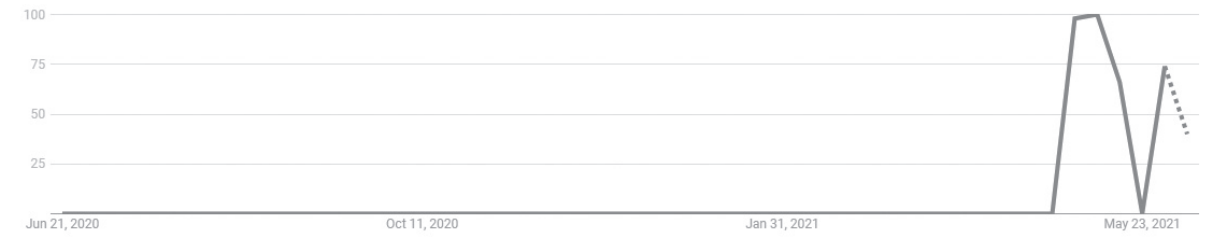

Wykres 3. Zainteresowanie kosmetykami firmowanymi przez youtuberkę Natsu

Źródło: opracowanie własne. 


\section{Prostytucja jako element rynku}

Definicję rynku jako mechanizmu koordynującego zachowania nabywców i sprzedawców uczestniczących w procesie wymiany dóbr oraz usług ${ }^{31}$ można z łatwością odnieść do zjawiska oferowania cielesności i seksualności. Historię nowoczesnej komercjalizacji zjawiska prostytucji można liczyć od połowy XX wieku. W 1969 roku Dania jako pierwsza zalegalizowała prostytucję i uznała ją za zawód. Prostytucja to — zgodnie z definicją — oddanie własnego ciała do dyspozycji większej liczbie osób w celu osiągnięcia przez nie zaspokojenia seksualnego i pobieranie za to wynagrodzenia. W przypadku prostytucji zachodzi więc świadczenie usług $\mathrm{w}$ dziedzinie seksu, polegających zwykle na odbywaniu stosunków płciowych lub ich symulowaniu za pieniądze lub inne korzyści ${ }^{32}$. Inna definicja określa prostytucję jako różnorodne w formie kontakty hetero- lub homoseksualne uprawiane w celach zarobkowych z większą liczbą osób. Stosunek prostytucyjny traktowany jest w kategoriach rzeczowych (usługowych) i wyklucza więź emocjonalną. Prostytucja traktowana jest jako usługa, a ciało osoby prostytuującej się jako towar, za który klient musi zapłacić, aby go nabyć ${ }^{33}$.

Tak jak zmieniało się w historii kultury podejście do seksualności, tak zmieniało się podejście do prostytucji. Kulturowe uwarunkowania prostytucji wynikają stąd, że prostytucja jako zinstytucjonalizowana forma regulacji życia seksualnego jest uzależniona od porządku społecznego panującego w danej kulturze ${ }^{34}$.

Istniejące w starożytnej Grecji prostytucja religijna i prostytucja gościnna nie spotykały się z napiętnowaniem. Również w staroży tnym Rzymie domy publiczne i prostytucja rozwijały się bez społecznego potępienia ${ }^{35}$. Początkowo działo się to w kręgach nieświątynnych, a następnie w szerszym zakresie. Wszystkie prostytutki publiczne - quaestuariae - zgodnie z obowiązującym prawem podzielone zostały na prostytutki zarejestrowane (meretrices) i niezarejestrowane (prostibulae). Wśród tych drugich utworzyło się jedenaście kategorii kobiet, świadczących szeroką gamę usług heteroseksualnych. Istniały też kategorie dzieci i młodzieńców świadczących usługi seksualne ${ }^{36}$.

Perspektywa historyczna budująca obyczajowość świata zachodu była procesem długotrwałym i etapowym. Średniowieczna moralność potępiała w zasadzie prostytucję, jednak praktyka dowodziła, że to zjawisko było tolerowane. W tej epoce specyficzną rolę odgrywały kąpiele, często służące do relaksu, masaży

31 D. Begg, S. Fischer, R. Dornbusch, Mikroekonomia, przeł. B. Czarny et al., Warszawa 2007, s. 77.

32 W. Kopaliński, op. cit., s. 373.

33 Z. Lew-Starowicz, Stownik seksuologiczny, Warszawa 1986, s. 70.

34 K. Imieliński, Manowce seksu — prostytucja, Łódź 1990, s. 23.

35 K. Charkowska, Zjawisko prostytucji w doświadczeniach prostytuujacych się kobiet, Kraków 2010, s. 14.

36 B. Hołyst, Kryminologia, Warszawa 2001, s. 154. 
i seksu. Były one nieodłącznym elementem gościnności, ważnym punktem prywatnej przestrzeni, intymnych związków ${ }^{37}$. Prostytutek w tej epoce nie szanowano. Traktowano je z pogardą: mieszkały w osobnych dzielnicach, nosiły stroje odróżniające je od innych kobiet (czerwona przepaska na rękawie, tak zwana gilda). Nie mogły wnosić aktu oskarżenia za gwałt na nich, nie mogły otrzymywać spadków ani sporządzać testamentów. Kiedy umierały, chowano je na osobnych cmentarzach, poza miastem. Zarówno ograniczenia prawne, jak i moralne sprawiły, że prostytutki żyjące w epoce średniowiecza naprawdę znajdowały się poza nawiasem społeczeństwa ${ }^{38}$. Kościół usiłował pomagać prostytutkom pragnącym powrócić na drogę cnoty. Za jego sprawą powstawały schroniska Magdaleny dla nawróconych grzesznic, gdzie miały się one oczyszczać z grzechów. Niestety władze państwowe musiały je zlikwidować i zakazać powoływania nowych, gdyż przybytki te zaczęły się przekształcać w domy publiczne ${ }^{39}$.

Czasy reformacji stworzyły instytucję kurtyzany — eleganckiej prostytutki. Mimo tych działań wydaje się, że społeczna funkcja prostytutki traciła na znaczeniu. Skrajne odłamy religii reformowanych (purytanie) stawiały czystość moralną jako wartość nadrzędną. Prostytucja była nieakceptowalna i stała się tabu. Doprowadzano powoli do sytuacji, w której można było korzystać z usług prostytutek, ale nie wypadało o tym mówić. W tym przypadku ujawnia się tabu w pierwotnej formie. Zakazem obejmuje się prostytucję, grożąc sankcjami społecznymi, nie wyklucza się jej jednak fizycznie. Francja na przykład poszła bardziej w kierunku reglamentacji niż zakazu prostytucji. Na początku 1796 roku Napoleon Bonaparte nakazał stworzyć spis prostytutek w stolicy. Z początkiem XIX wieku nakazano im wizyty lekarskie, by wyeliminować szerzące się choroby weneryczne. Naukową teorię o patologicznych źródłach prostytucji — wrodzonej skłonności części kobiet do rozpusty - stworzył włoski psychiatra i antropolog Cesare Lombroso $^{40}$. W myśl tej teorii, „naukowo podbudowanej wynikami masowych pomiarów antropologicznych", prostytutka rodziła się z dyspozycjami charakterologicznymi (,urodzona prostytutka”) do tego zajęcia. Stąd miały wynikać u prostytutek wzmożony popęd płciowy, lenistwo, próżność oraz cechy dewiacyjne. Biologicznymi uwarunkowaniami tłumaczono trudne do pojęcia, zwłaszcza dla kobiet, oddawanie się prostytucji przez osoby, których warunki materialne do tego nie zmuszały ${ }^{41}$. Jak można dostrzec, tabu uzyskało podbudowę formalną. Co ciekawe, nawet środowiska kobiece zaczęły tworzyć lub wspierać teorię dyskryminującą społecznie prostytucję.

\footnotetext{
37 Historia życia prywatnego..., s. 397.

38 K. Imieliński, op. cit., s. 70.

39 Ibidem, s. 72.

40 A. Mościskier, Natura ludzka i problem przestępczości, Warszawa 2001, s. 133.

41 J. Sikorska-Kulesza, Zło tolerowane, Warszawa 2004, s. 323.
} 
Prawdą jest, że feministki w XIX i XX wieku zwykle źle zachowywały się wobec prostytutek, tj. zamiast ich bronić, gdy były — i są — jako kobiety pomiatane przez psychopatów, sądownictwo i religijnych moralistów, powtarzały za patriarchalistami, że prostytucja jest złem [...] lub tworzyły utopijne uwagi [...] jak będzie, gdy kiedyś prostytucja zniknie. Tym samym ruch feministyczny ma obciążone sumienie cierpieniem, a nawet śmiercią wielu kobiet, za którymi się nie ujął, a mógł $x^{42}$.

Szukano więc bardziej przyczyny lub winy, nie było mowy o akceptacji tego zjawiska.

Współcześnie prostytucja podlega w Polsce stygmatyzacji. Nie znaczy to, że zarówno pornografia, jak i prostytucja nie podlegają komercjalizacji. W odniesieniu do polskich realiów komercjalizacja prostytucji odbywa się w sposób interesujący. Na terenie Polski prostytucja jest legalnym procederem, jednak nie podlega regulacji prawnej. Penalizowane jest stręczycielstwo, czyli czerpanie zysków z prostytucji. Zgodnie z art. 204 kodeksu karnego:

$\S 1$. Kto, w celu osiągnięcia korzyści majątkowej, nakłania inną osobę do uprawiania prostytucji lub jej to ułatwia, podlega karze pozbawienia wolności do lat 3 .

$\S 2$. Karze określonej w $\S 1$ podlega, kto czerpie korzyści majątkowe z uprawiania prostytucji przez inną osobę.

$\S$ 3. Jeżeli osoba określona w $\S 1$ lub 2 jest małoletnim, sprawca podlega karze pozbawienia wolności od roku do lat 10.

$\S 4$. Karze określonej w $\S 3$ podlega, kto zwabia lub uprowadza inną osobę w celu uprawiania prostytucji za granicą ${ }^{43}$.

Ponieważ osoby zajmujące się prostytucją nie powołują na terenie Polski formalnych organizacji, nie ma mowy o swobodnym budowaniu wspólnego wizerunku. Funkcjonowanie prostytucji w strukturach rynku pracy (co wiąże się z ochroną praw pracowniczych, prawami emerytalnymi, opodatkowaniem), pociąga za sobą powstawanie formalnych organizacji. W Holandii, Niemczech czy Francji powstały związki zawodowe osób zajmujących się prostytucją. W polskich realiach gospodarczych osoby uprawiające ten zawód to jednak odosobnione podmioty, będące osobnymi wyspami na rynku. $Z$ jednej strony jest to więc idealne rozwiązanie dla samodzielnych podmiotów, z drugiej — pociąga za sobą brak jednolitej wizji rynku czy usługi, wizji kreowanej przez organizacje pracownicze.

$\mathrm{Na}$ temat prostytucji w kontekście wizerunku wypowiedzieli się twórcy raportu o tym zjawisku na Dolnym Śląsku. Wizerunek własny osoby prostytuującej się, niezależnie od badanych zbiorowości, jest bardzo zbliżony. Większość respondentów wskazywała na neutralną lub też bierną ekspozycję własnej seksualności. Natomiast coraz rzadziej osoby uprawiające ten proceder identyfikowane były przez pryzmat czynnej ekspozycji seksualności, skorelowanej z konkretnymi działaniami: utrzymywaniem stosunków seksualnych z maksymalnie dużą

42 L. Ostasz, Elementy kulturoznawstwa, Olsztyn 2000, s. 303.

43 Tekst jedn. Dz.U. z 2020 r. poz. 1444, 1517; z 2021 r. poz. 1023. 
liczbą partnerów, zachowywaniem się w sposób wyzywający czy eksponowaniem swego seksapilu ${ }^{44}$.

Podmioty handlujące seksualnością reklamują swój towar w internecie, dokąd przeniósł się prawie cały przemysł związany z seksualnością i cielesnością. Według badań przeprowadzonych wśród polskich internautów 96\% mężczyzn i 78\% kobiet deklaruje korzystanie ze stron WWW, zawierających treści pornograficz$n e^{45}$. Według Pornhub Polska stanowi dwunasty kraj na świecie pod względem konsumpcji treści porno. Swobodnie funkcjonują bazy ogłoszeń anonsów: pań, panów oraz par, stanowiące szeroki i bogaty materiał badawczy.

\section{Analiza treści ogłoszeń towarzyskich pod względem wykorzystywanych środków komunikacji}

Dwa największe serwisy ogłoszeń towarzyskich to Odloty.pl i Roksa.pl. Notują one, według danych właścicieli, około 120-170 tys. unikatowych odwiedzin w ciągu miesiąca ${ }^{46}$.

Ich popularność potwierdzona jest najwyższym pozycjonowaniem przez wyszukiwarki internetowe. Są to dobrze rozbudowane strony, z opisem w kilku językach obcych. Same jednak pośredniczą tylko w transakcji. Model biznesowy serwisów opiera się na poborze opłat za ogłoszenie.

Treścią i rzeczywistym produktem są same ogłoszenia, które każdorazowo składają się z parametrów technicznych, opisu oferty i ilustracji. Ze względu na sformatowanie elementów trudno odnosić się w analizie do ich odmienności jako do głównego przymiotu tworzącego różnicę. Wydaje się, że bardziej wskazane jest zwrócenie uwagi na samą zawartość ogłoszeń. Aby uzyskać pełny przegląd, do analizy wylosowano po dziesięć ogłoszeń z każdego województwa, znajdujących się w serwisie. Ogłoszenia dobierano z wylosowanych miast w obrębie województwa. Dobór ten pozwolił na wyłonienie 160 ogłoszeń. Analizę przeprowadzono pierwszy raz w roku 2014, a drugi raz w 2021. Siedem lat różnicy powinno uwypuklić zmieniające się tendencje i trendy. Liczba przebadanych oferentów stanowi zadowalającą ze względów statystycznych próbę, która pozwoli zarysować tendencje komercjalizacji tego obszaru.

\section{Analiza warstwy graficznej}

Analizie podlegać będą dwie warstwy — tekstowa oraz graficzna. Badanie rozpoczęto od analizy grafiki ilustrującej ogłoszenia osób zajmujących się prostytu-

44 J. Kurzępa, A. Lisowska, A. Pierzchalska, Prostytucja ,nieletnich” w perspektywie Dolnośląaków. Raport z badań, Wrocław 2008, s. 17.

45 Z. Izdebski, Raport o seksualności Polaków w internecie, 2010, https://docplayer.pl/9773600-Seks-polakow-w-internecie-raport-polpharmy-2010-prof-dr-hab-zbigniew-izdebski.html (dostęp: 5.06.2021).

46 Google Analitycs, dane z października-listopada 2018. 
cją. Pierwszą informacją, jaką udało się uzyskać, jest liczba zdjęć towarzysząca ogłoszeniom. Średnia liczba fotografii to sześć na jedno ogłoszenie w roku 2014 i osiem — w roku 2021. Wzrost jest więc zauważalny i statystycznie istotny. Na zdjęciach zwykle prezentowane są różne ujęcia. Pozy przedstawione na fotografiach są wyzywające, jednoznacznie seksualne i zwykle ukazują atrybuty seksualne osób świadczących usługi. Na fotografiach prezentowane są osoby ubrane w bieliznę lub w stroje podkreślające seksualność. Całkowita nagość była przedstawiona na 23\% zdjęć w roku 2014 i 20\% w roku 2021. Stworzenie przejrzystej klasyfikacji ujęć było utrudnione ze względu na brak możliwości dokładnego ich określenia i problemy z kategoryzacją, a także niewielką relewancję w kontekście omawianego tematu. Zjawisko profesjonalizacji zdjęć, rozumianej jako widoczne ślady „zaaranżowania”, występowanie profesjonalnego tła fotograficznego czy też mniejsze lub większe ślady obróbki cyfrowej, było o $25 \%$ bardziej widoczne w próbce pobranej w roku 2021.

Co najmniej jedną pozycję seksualną prezentuje $88 \%$ zdjęć. Warstwa graficzna ogłoszeń nie pozostawia wątpliwości co do charakteru świadczonych usług. Prezentowanie w ofertach biustu, nagiej sylwetki czy penisa jest zdecydowanie mechanizmem, który ma podkreślić najistotniejsze cechy towaru.

Komercjalizacja prostytucji bezpośrednio łączy się z ukazywaniem nagości. Ciało staje się więc towarem, który jest sprzedawany. Nie jest to wniosek odkrywczy, jednak należy go postawić w kontekście zebranego materiału. Twórcy serwisu przeciwdziałającego fałszowaniu i kradzieży zdjęć zaproponowali klientom mechanizm uwiarygodnienia towaru sprzedawcy. W odróżnieniu od 2014, w 2021 pojawia się więc świadectwo, swoistego rodzaju certyfikat, potwierdzający realność towaru sprzedawanego w ogłoszeniu. Serwis więc oznacza profile komunikatem: Zdjęcia autentyczne, zweryfikowane! Dodatkowo pojawia się możliwość przeczytania recenzji użytkownika, tak jak w wielu sklepach internetowych czy serwisach typu Booking.com. Opisany mechanizm weryfikacji ma wykluczyć nieuczciwą konkurencję. Jest to tym bardziej ciekawe, że mechanizm ten stanowi jedno z narzędzi regulacji rynku wytworzonych wewnątrzsystemowo.

Inne kategorie podlegające analizie to dodatki, które każdy sprzedający deklaruje w obrębie modelu zaproponowanego przez punkt dystrybucji ogłoszenia. Konkurencyjność wzrasta dzięki znajomości języków obcych czy wydłużeniu godzin pracy (aktywnego świadczenia usług).

\section{Analiza nazw ogłoszeń}

$\mathrm{Na}$ wstępie analizy warstwy tekstowej należy ustosunkować się do namingu. Jak dało się zaobserwować, nazwy wykreowane są dość szablonowo. Mamy w tym wypadku do czynienia ze ścisłym skonwencjonalizowaniem rynku w aspekcie namingu. Analiza i kategoryzacja pozwoliły posegregować oferty na pięć dużych kategorii. 
1. Imię lub imię i przymiotnik określający osobę wykonującą usługi.

Występowanie:

— w 2014 w 72 ofertach na 160,

— w 2021 w 68 ofertach na 160.

W tej kategorii znajdują się na przykład: „Niesamowita Ewelinka”, „Olivka”, „Sandra”, „Yennefer”, „Posłuszna Kate”. Kategoria ta wydaje się mieć największe znaczenie, jeśli chodzi o budowanie wizerunku. Jak wspomniano wcześniej, już na etapie nazwy produkt próbuje się różnicować. Kategoria ta jest największa, ale jednocześnie najbardziej różnorodna. Ponieważ wstępna selekcja ofert odbywa się poprzez nazwę i zdjęcie, te dwa elementy stanowią istotny wyróżnik wizerunkowy.

2. Opisowe odniesienia funkcji.

Występowanie:

- w 2014 w 32 ofertach na 160,

- w 2021 w 30 ofertach na 160.

Przykładami są takie nazwy jak: „Dojeżdżam tylko dla pań”, ,Tylko kilka dni”, „Magda robię wszystko”. Wydaje się, że określnik jest pewnego rodzaju sloganem reklamującym rodzaj usługi lub eksponowaną cechę. Można więc odnaleźć na przykład: „Ostrą Nauczycielkę”, , Zmysłową Sekretarkę, ,,Seksownego Diabełka”. Funkcjonalność jest elementem stałym opisu oferty i wydaje się, że występuje brak istotności statystycznej wzrostu w tym obszarze.

\section{VIP}

Występowanie:

- w 2014 roku w 20 ofertach na 160,

— w 2021 roku w 35 ofertach na 160.

W tej kategoria ofert, które już na etapie namingu starają się być klasyfikowane wyżej niż pozostałe, znajdują się między innymi: „Klaudia prestige”, „HotOliviaVIP”, „Czarna Diablica Luxx”. Istnieje tu korelacja między ceną a przynależnością oferty do kategorii VIP. Oferty z tej kategorii są droższe średnio o 50\% od pozostałych. Co ciekawe, w 2021 roku wystąpił wzrost liczby ofert, w których nazwie znajduje się dopisek „VIP” lub ,exclusive”. To ciekawy zabieg świadczący o dywersyfikacji rynku produktów o takich samych cechach i podobnych funkcjonalnościach, ale innych korzyściach symbolicznych.

4. Imię lub przydomek — określenie wieku osoby.

Występowanie:

— w 2014 roku w 24 ofertach na 160,

— w 2021 roku w 20 ofertach na 160.

Wśród ogłoszeń występują: „Ania 26”, „Świeża 18 nowa”, ale także ,„para i dwie młode ładne laski”. Co ciekawe, wydaje się, że im starsza osoba, tym mniej chętnie chwali się wiekiem. Nie znaczy to jednak, że nie zdarzają się takie przypadki. Można nawet zaryzykować stwierdzenie, że jest to poszukiwanie swojej przestrzeni na rynku. Jak widać, działania z zakresu namingu są obecne w tym jego obszarze. 


\section{Inne:}

— w 2014 roku w 12 ofertach na 160,

— w 2021 roku w 7 ofertach na 160.

Przykłady to „Łasiczka”, „Blondi 8”, „,cukiereczek”, „Number one”. Analizowane nazwy ofert są różnorodne, ale niedające się klasyfikować w kategorie. Niewielka częstotliwość występowania określeń z kategorii „inne” świadczy o skonwencjonalizowaniu branży.

\section{Analiza treści ogłoszeń}

Osoby zajmujące się prostytucją próbują wykorzystać każdą przestrzeń do budowania wizerunku. Oprócz fotografii wyróżnikiem ofert jest warstwa tekstowa. Każdemu ogłoszeniu, każdej ofercie towarzyszy opis, który stanowi jej dodatkowy składnik. Analiza tekstowa ukazuje interesujące elementy, którymi oferenci przyciągają klientów. Wizerunkowo sprzedawany jest obraz rozkoszy i erotyzmu. O ile w 2014 roku komunikaty były krótkie i zwięzłe, o tyle siedem lat później narracja jest bardziej rozbudowana. W zasadzie bezpośrednio mówi się o seksie, określając jego rodzaje oraz sposoby jego uprawiania. Konwencja opisu jest stosunkowo szeroka. Najczęściej występującym wskazaniem w opisie jest odniesienie do dyskrecji.

Osoby zajmujące się prostytucją przy komercjalizowaniu swojej usługi mają świadomość tabu. Warstwa tekstowa wskazuje na możliwe konsekwencje społeczne korzystania z usług seksualnych. Sprzedawcy minimalizują więc ryzyko odrzucenia oferty. Jest to element występujący w blisko $80 \%$ wszystkich tekstów w 2014, ale tylko w 60\% w 2021. Wydaje się, że również druga kategoria — higiena - ujmuje aspekt zagrożenia. W tym przypadku nie chodzi o sankcje społeczne, ale o zdrowie. Wydaje się, że higiena jest zadeklarowaną gwarancją bezpieczeństwa zdrowotnego. Świadomość istnienia zagrożeń epidemiologiczno-sanitarnych związanych z uprawianiem przygodnego seksu może odstraszać klientów. Jak wykazują badania seksualności Polaków, ponad 41\% obawia się chorób przenoszonych drogą płciową, HIV, AIDS ${ }^{47}$. Wdrożenie środka kreacji wizerunkowej, mającego zapewniać o higienie i bezpieczeństwie, ma przeciwdziałać tym obawom.

Wiele odniesień w warstwie tekstowej reklamuje bezpośrednio ciało. Mowa tu o kształtach i rozmiarach. Można zaryzykować stwierdzenie, że gdyby nie specyficzna treść ogłoszeń, należałoby opis ten zaliczyć do właściwości technicznych. To trend, który również został uwypuklony w 2021 roku. Odniesienia te stanowiły o 11\% więcej niż w roku 2014. Autorzy i autorki tekstów kreują swój wizerunek jako osób o młodym, jędrnym ciele. Ważnym odniesieniem jest tu wspomniany wcześniej kult piękna, witalności i młodości, funkcjonujący jako wzorzec normatywny. Osoby prostytuujące się zachwalają swoje ciała w określony sposób, zbliżający się do kreowanego wzorca. Mężczyźni piszą więc o mięśniach, kobie-

47 Z. Izdebski, op. cit. 
ty zapewniają o szczupłej sylwetce i dużym rozmiarze biustu. Kolejna kategoria to temperament, istotny czynnik próbujący wyróżnić ofertę. Bardzo mała liczba określeń sprawia, że trudno o głębszą analizę tego pola semantycznego. Osoba oferująca płatny seks zwykle przedstawia się jako namiętna, czuła, sympatyczna i temperamentna, bez względu na to, czy mowa o roku 2014 czy 2021. Konwencja zabija indywidualność, przez co trudno dywersyfikować usługę w tym względzie. Jedynie oszczędność w słowach odróżnia jedne ogłoszenia od drugich.

Ostatnia analizowana kategoria — zakazy — to różnego rodzaju deklaracje, wymagania i ograniczenia dotyczące klientów. Są to warunki, jakie stawia się przed transakcją. Tak więc są oferty skierowane tylko do trzeźwych, tylko wyjazdowe lub podkreślające brak akceptacji dla określonych praktyk seksualnych. Można traktować je jako swego rodzaju instrukcję obsługi. Co ciekawe, wraz z upływem czasu poszerza się zakres akceptowanych praktyk. Coraz więcej oferentów proponuje coraz szerszy zakres usług. W 2014 roku 35\% tekstów zawierało deklarację oferenta o tym, czego nie toleruje, tymczasem siedem lat później jest to tylko 20\%. Można wysnuć wniosek, że wynika to z renegocjacji normatywu, który odnosi się do proponowanej usługi.

\section{Podsumowanie}

Na podstawie przytoczonych przykładów można postawić tezę, że seksualność profesjonalizuje się przy użyciu narzędzi dostępnych na rynku i wypracowanych przez inne branże. Od lat przemysł ten korzystał z pełnej palety istniejących rozwiązań. Zauważalna jest powszechność owego zjawiska. Świadomość elementów związanych z autokreacją, przeliczona na kapitał, umożliwia dziś wyjście poza sferę tabu. Oczywiście, poczucie wstydu ciągle towarzyszy osobom czerpiącym korzyści z handlu seksem. Objawia się to w powszechnym zakrywaniu twarzy w ogłoszeniach towarzyskich czy zakładaniu masek oraz kadrowaniu filmów, tak by uniemożliwić rozpoznanie aktorów. Na zbudowanym z tabu murze pojawiają się jednak pęknięcia. Gwiazdy show-biznesu żyją z eksplorowania swojej seksualności. Osoby, które dziesięć czy piętnaście lat temu byłyby spychane na margines ze względu na eksplorację branży usług seksualnych, dziś odnaleźć można w telewizji śniadaniowej. Rosnąca świadomość narzędzi tworzy influencerów, rozumianych jako ludzi wpływu. Swoim przykładem ukazują, że seks z zespołem muzycznym w autobusie może być ścieżką kariery. Prostytutki reklamują swój towar, czerpiąc wprost z koncepcji Philipa Kotlera. Pozycjonowanie na rynku, dywersyfikacja koszyka produktów, ekwiwalencja jakościowa stosowana w praktyce nie tylko maksymalizują zyski, lecz także poszerzają grono klientów. To drugi wyłom w murze wstydu zbudowanym ze społecznego tabu. Konstrukcja ta chwieje się coraz mocniej. Warto przyglądać się tej branży nie tylko ze względu na znaczenie i rolę w kształtowaniu modeli normatywnych dotyczących zachowań seksualnych, 
lecz także ze względu na ogromne zyski, które ona generuje. Są one fundamentem rozwoju i sięgania po kolejne narzędzia do burzenia muru tabu.

\section{Bibliografia}

Adamiak E., Kobieta w Kościołach i wspólnotach chrześcijańskich. Próba syntezy teologicznej, „Poznańskie Studia Teologiczne” 11, 2011.

Beck M., The Roots of Western Pornography. The French Enlightenment Takes on Sex, Oxford 2003.

Begg D., Fischer S., Dornbusch R., Mikroekonomia, przeł. B. Czarny et al., Warszawa 2007.

Ciereszko M., Popularna pornografia? O rodzajach pornografi funkcjonujacych na ziemiach polskich na początku XX wieku i jej relacji z ówczesna kultura popularna, „Kultura i Historia” 2016, nr 296.

Charkowska K., Zjawisko prostytucji w doświadczeniach prostytuujących się kobiet, Kraków 2010.

Douglas M., Czystość i zmaza, przeł. M. Bucholc, Warszawa 2007.

Historia życia prywatnego, red. G. Duby, t. 2, Wrocław 1998.

Dover K.J., Homoseksualizm grecki, przeł. J. Margański, Kraków 2004.

Imieliński K., Manowce seksu - prostytucja, Łódź 1990.

Jakubowska H., Ciało i seksualność jako narzędzie przyjemności i źródto cierpienia, [w:] Przemiany seksualności, red. M. Kaczorek, K. Stachura, Gdańsk 2009.

Jasińska-Kania A., Wartości i normy moralne a procesy przemian w Polsce i Europie, [w:] Wartość, postawy $i$ więzi moralne $w$ zmieniającym się społeczeństwie, red. J. Mariański, L. Smyczka, Kraków 2008.

Foucault M., Body/Power, [w:] idem, Power/Knowledge, red. G. Colin, London 1980.

Hankus M., ,,Powabny wydźwięk ciat” a kreacja nowej sztuki religijnej, „Zeszyty Naukowe Towarzystwa Doktorantów UJ. Nauki Humanistyczne" 2011, nr 31.

Hołyst B., Kryminologia, Warszawa 2001.

Izdebski Z., Seks Polaków w Internecie. Raport Polpharmy, 2008, https://docplayer.pl/9773600-Seks-polakow-w-internecie-raport-polpharmy-2010-prof-dr-hab-zbigniew-izdebski.html.

Kalwin J., Zasady religii chrześcijańskiej (1559-1560), [w:] Historia doktryn artystycznych, t. 2. Teoretycy, pisarze i artyści o sztuce 1500-1600, red. J. Białostocki, Warszawa 1985.

Kopaliński W., Słownik wyrazów obcych i zwrotów obcojęzycznych, Warszawa 1989.

Kultys, J.A., Moralność a seks i kobiety (w wybranych kulturach), Słupsk 1999.

Kuraciński E., Wyznaczniki kultury masowej, „Seminare. Poszukiwania naukowe” 21, 2005.

Kurzępa J., Lisowska A., Pierzchalska A., Prostytucja ,nieletnich” w perspektywie Dolnoślazaków. Raport z badań, Wrocław 2008.

Leksykon Public Relations, red. J. Olędzki, D. Tworzydło, Rzeszów 2009.

Leśniewski M., Narodziny seksuologii - zarys stanu wiedzy lekarskiej o seksualności człowieka na przełomie XIX i XX wieku, [w:] Kobieta i rewolucja obyczajowa. Spoleczno-kulturowe aspekty seksualności. Wiek XIX i XX, red. A. Żarnowska, A. Szwarc, Warszawa 2005.

Lew-Starowicz Z., Miłość i seks: Stownik encyklopedyczny, Wrocław 1998.

Lew-Starowicz Z., Stownik seksuologiczny, Warszawa 1986.

Łojek J., Nagość ciała w obyczajowości i kulturze Europy, „Teksty” 33, 1977, nr 3.

Mauss, M., Socjologia i antropologia, przeł. M. Król, K. Pomian, J. Szacki, Warszawa 2001.

Melosik Z., Tożsamość, ciało i władza. Teksty kulturowe jako (kon)teksty pedagogiczne, Poznań 1996.

Mościskier A., Natura ludzka i problem przestępczości, Warszawa 2001.

Nijakowski L.M., Pornografia. Historia, znaczenie, gatunki, Warszawa 2010.

Ostasz L., Elementy kulturoznawstwa, Olsztyn 2000. 
Petry Mroczkowska J., Amerykańska rewolucja seksualna - nie spetniona obietnica szczęścia, „Ethos” 32, 1995, nr 4.

Shusterman R., O sztuce życia. Od poetyki hip-hopu do filozofii somatycznej, przeł. W. Małecki, Wrocław 2007.

Sikorska-Kulesza J., Zło tolerowane, Warszawa 2004.

Stein A., Three Models of Sexuality. Drives, Identities and practices, [w:] Sexualities. Critical Concepts in Sociology, t. 1, red. K. Plummer, London-New York 2002.

Swaddling J., Starożytne igrzyska olimpijskie, Poznań 2004.

Wojciechowski M., Erotyka w mediach. Szansa czy zagrożenie dla rozwoju młodego pokolenia?, Kraków 1998. 